\title{
La visión en su cima: El método de los claros
}

$\mathrm{E}$ proyecto terminó por verse encuadrado entre dos imágenes. En uno de sus extremos, una secuencia de 1984 ilustra el regreso de María Zambrano a Espańa. La toma se registró, como es sabido, un 20 de noviembre de ese año. El fragmento no corresponde a una grabación en bruto sino a una emisión televisiva, ofrecida prácticamente en directo. En torno a las 16:38 horas de ese día (así consta, al menos, en un rótulo que figura sobreimpresionado en la imagen) Radiotelevisión Española interrumpió su programación, un magacín llamado "La tarde", para informar sobre el regreso de la pensadora exiliada. El fragmento discurre a lo largo de un único plano, sin cortes: dos minutos de duración en los que vemos cómo María Zambrano desciende, con dificultad, de una pequeña furgoneta a pie de pista y es conducida hacia la terminal del aeropuerto de Barajas. Además de Zambrano, en la imagen distinguimos, entre otras personas anónimas, a tres hombres que la acompañan y asisten durante el tiempo que ocupa la secuencia. Son Jaime Salinas, Rafael Tomero Alarcón y Jesús Moreno Sanz ${ }^{1}$. Zambrano abandona el vehículo apoyándose en el primero de ellos, éste la arropa con el abrigo blanco que ella lució aquella tarde y juntos se encaminan en dirección a la cámara que registra lo sucedido. El vídeo concluye con Zambrano atendiendo a las preguntas de la prensa, que la espera (reclama su atención a gritos y fotografía) tras una valla de alambre. Es por esta razón que la escena aparece filtrada por una celosía metálica. El fragmento se interrumpe cuando Zambrano ocupa ya por completo el primer plano del encuadre y comienza, aunque notablemente fatigada, a responder las preguntas de los periodistas.

\footnotetext{
Jesús Moreno, biógrafo y amigo personal de Zambrano, fue uno de los principales responsables de que su regreso se concretase en aquel momento. Además, fue él quien la acompañó en el vuelo que la trajo de vuelta desde Ginebra. Rafael Tomero es un familiar (primo hermano) de Zambrano cuya relevancia en su biografía es indudable; en momentos clave de su vida se preocupó por ayudarla y por mitigar, en la medida de lo posible, las dificultades económicas sufridas tanto por ella como por su hermana Araceli. Jaime Salinas, quien además de ser amigo personal de Zambrano e hijo del escritor (también exiliado) Pedro Salinas, dirigía, en aquel entonces, la Dirección General del libro en el Ministerio de Cultura.
} 


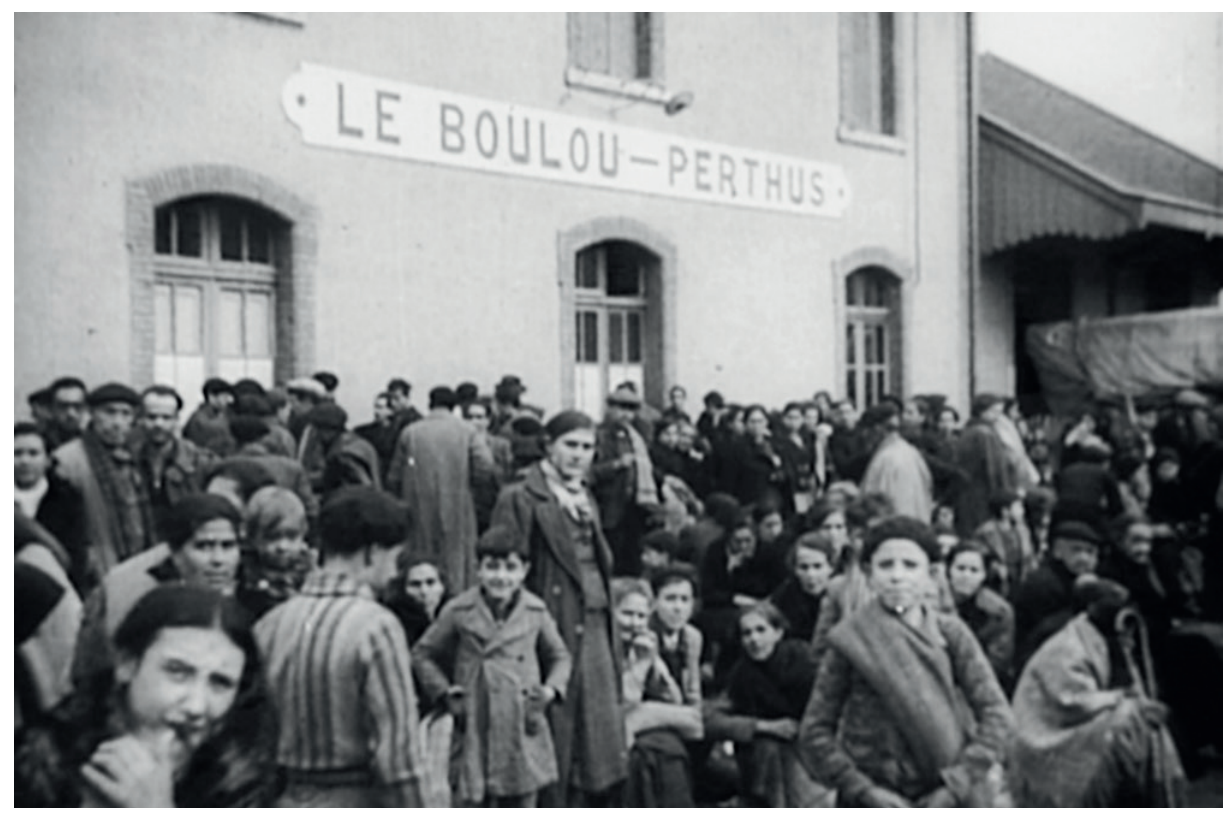

Frente a la de 1984, aunque sin ánimo de confrontarlas, se ha dispuesto otra imagen; esta última, realizada medio siglo antes. El segundo de los extremos lo ocupan fragmentos pertenecientes a un documental fechado en 1939 bajo el título de L'Espagne vivra ${ }^{2}$. Extraídas de este film de propaganda antifascista, citamos diversos planos que documentan la penosa salida de exiliados españoles a través de Le Perthus, ya finalizada la Guerra Civil. Es cierto que los dos márgenes comprenden, bajo la disposición descrita, el tiempo que ocupó el exilio de María Zambrano; también, claro está, los mismos lugares que emplazan el inicio y el final del mismo: Madrid y el año 1984 a su regreso, Le Perthus y el año 1939 en su salida. Ahora bien, aunque la referencia sea inevitable, conviene aclarar que con esas dos imágenes como marco no pretendíamos encerrar una mención "a todo lo que quedaría en medio de ellas". Ese tipo de elipsis es apenas lo mínimo que estas imágenes serían capaces de ofrecer. No están ahí, una frente a otra, para hacer constar el principio y fin de un exilio a partir de su silueteado, no para encerrar en su interior un asunto que ha de sobreentenderse. Desaprovecharíamos la verdadera aportación de esas imágenes si sólo las valoramos por lo que delimitan. Es

\footnotetext{
${ }^{2}$ Obra producida por el Secours populaire francés y dirigida por Henri Cartier-Bresson, cuenta también con comentarios en off firmados por Georges Sadoul.
} 
más, tomadas por límites, no hacen sino cegar una parte importante de eso que, efectivamente, "ciñen". La función deseable para cualquier imagen es una bien distinta, acaso la contraria a delimitar o contener: la imagen ha de ser un reclamo de visibilidad. En la convergencia de dos imágenes como estas lo deseable no es el paso ciego de una a otra, no podemos permitirnos reducir lo (que ha) pasado a un simple gesto metonímico. Las dos imágenes han de avivar la visión de lo que queda en medio, no suplantarlo.

\section{Ser objeto de mirada}

Anota Zambrano: "El exiliado es él mismo ya su paso, una especie de revelación que él mismo puede ignorar, e ignora casi siempre como todo ser humano que es conducido para ser visto cuando él lo que quiere es ver. Pues el exiliado es objeto de mirada antes que de conocimiento" ${ }^{3}$. Ser objeto de mirada: ¿qué supone esta cualidad en una época en la que el ser observado parece llevar implícita una amenaza? ¿Son equivalentes el ser objeto de mirada y el ser observado? La observación que acaso envuelve una amenaza sería aquella que, entendemos, prejuzga al individuo; la que únicamente ve en ese individuo a un potencial delincuente, a un consumidor, a un operario sujeto a normas de comportamiento o a un rendimiento laboral que se le demanda... Pero es que estos individuos, los que así son observados, están siendo tomados por objeto de vigilancia y no de mirada; la diferencia es substancial. Quien vigila sólo tiene en vista hallar evidencias; el resto de lo observado, en el objeto de atención, es irrelevante, es deshecho. Ser objeto de mirada, al menos en el sentido en que Zambrano incide en ello, implica una disposición por completo opuesta al prejuicio. En este caso, el objeto de atención es algo que se abraza con la mirada, que nada deshecha en ese objeto. Zambrano, en esa misma cita, propone distinguir entre ser objeto de mirada y ser objeto de conocimiento. No es que con ello advierta que la figura del exiliado sea incapaz de convertirse también en objeto de conocimiento; simplemente, antepone el ser objeto de mirada en su caso. Con ello, lo que busca es apartarlo o alzarlo por un instante, concederle una suerte de preámbulo en nuestra aproximación. Ser objeto de mirada es gozar de un margen en el que desenvolverse en cuanto algo distinto que surge a la vista, rodeado por una indeterminación inicial en la que apenas se vislumbra la posibilidad del significado. Nuestra intención fue la de respetar ese margen para las imágenes de los extremos mencionadas al inicio, que apareciesen

3 Zambrano, M., Los bienaventurados, Ediciones Siruela, Madrid, 2004, pp. 32-33. 
como objetos de mirada y no como señales que contienen (en el sentido de que lo sujetan y hasta lo amordazan) un argumento.

Lo ideal es que en ellas obre la metáfora elegida por Zambrano: las dos imágenes de los extremos, así como las que a través de ellas fueron surgiendo, deberían actuar como los claros de un bosque. Es indudable que para María Zambrano el claro del bosque es un objeto de mirada primordial. Ella abraza la "analogía del claro" de un modo que trasciende en mucho el juego metafórico: "alguna figura en esta lejanía anda a punto de mostrarse al borde de la corporeidad, o más bien más allá de ella, sin ser un esquema ni un simple signo. Figuras que la visión apetece en su ceguera nunca vencida por la visión de una figura luminosa ni por esplendor alguno(...). Y la visión lejana del centro apenas visible, y la visión que los claros del bosque ofrecen, parecen prometer, más que una visión nueva, un medio de visibilidad donde la imagen sea real y el pensamiento y el sentir se identifiquen sin que sea a costa de que se pierdan el uno en el otro o de que se anulen. Una visibilidad nueva, lugar de reconocimiento y de vida sin distinción, parece que sea el imán que haya conducido todo este recorrer análogamente a un método de pensamiento" ${ }^{4}$. En Claros del bosque lo que se nos descubre es un dietario con el que su autora recapitula la experiencia de un tiento. Ese libro es un puro ejercicio de visibilidad que encontró acomodo en un centro propicio, en un espacio escondido a los pies del Jura, en el lugar de La Pièce.

\section{Mirar un lugar}

Es ahora cuando quizás convenga aclarar que el motivo original del proyecto expositivo y documental aquí referido era, inicialmente, el de la búsqueda (y registro en imágenes) de lugares relativos al período europeo en el exilio de María Zambrano. De inicio, lo que se pretendía era realizar un sondeo a través de lugares de escritura. El primero de ellos y fundamental, La Pièce; pero también Segovia, Paris, Roma, Nápoles, Ginebra, Atenas... En pocos autores como en Zambrano reconoceremos una disposición tan particular a habitar (y dejarse habitar) por la escritura. En su caso, la escritura parece contener, como si se tratase de su horma, algo esencial del rincón en el que fue escrita. En base a este convencimiento buscamos, ingenuamente, indicios del arraigo de su escritura en los lugares; sin duda, fuimos cegados por lo vívida que se muestra esa relación a la inversa. María Zambrano fue capaz de palpar las costuras internas de la existencia humana; de ese labio sagrado dio cuenta en meditaciones escritas que son, sin embargo y todavía, textos tremendamente tangi-

4 Zambrano, M., Claros del bosque, Cátedra, Madrid, 2011, edición de Mercedes Gómez Blesa, pp. 123-124. 
bles, terrenales. Ese fue el espejismo que nos empujó a buscar en los lugares huellas de co-pertenencia, de una soñada permeabilidad mutua entre su escritura y los espacios que la hicieron posible durante el exilio. ¿Dónde, sino en los lugares en los que ella se vio, a sí misma, privada del lugar -ella que tanto dependía de los lugares para dar fundamento a su escritura- podríamos observar con propiedad todo lo que en su pensamiento tiene lugar? En efecto, la peregrinación a estos lugares sirvió para aplacar, antes que nada, la sed de proximidad que sentíamos por lo leído en Claros del bosque. Fue a partir de ese arrebato inicial cuando las propias imágenes fueron aflorando y convergiendo, como si se desprendieran con naturalidad de un fondo, de una historia ensombrecida por el paso del tiempo y por los estereotipos (que también se han acumulado, en abundancia y por desgracia, sobre la figura de Zambrano). Partiendo de la atención a la idea de lugar en su obra, el proyecto terminó drenando imágenes e historias que pedían ser objeto de mirada.

Una de estas imágenes fue la del exiliado visto como un fantasma en perpetuo retorno incumplido. A falta del lugar que entiende como propio, el espacio que lo acoge no deja de asaltar al exiliado desde su provisionalidad, a mostrarse como la notación dolorosa de un habitar sin reposo. La tierra abandonada es un irremediable lugar por venir; así lo asume el exiliado, pero esa es una razón que la visión no acepta. Ella, movida por el deseo, va un cuerpo por delante del propio cuerpo del que procede. He aquí una de las claves en la situación trágica que sufre el exiliado: el inconformismo congénito de su mirada resiste. Y es entonces, en la mirada que resiste o que se resiste a renunciar, en donde un síntoma de su condición como espectro en vida se manifiesta intensamente. La forma en que la mirada tiende a exceder al cuerpo se acentúa. Más que nunca, la mirada yerra fuera de sí, se encuentra más enajenada aún de lo que en ella es natural. La condición espectral del exiliado es una de las figuras sobre las que, dentro de las meditaciones que Zambrano consagra a este español sin España y a su mirada, más se insiste. Los exiliados (incluida aquella mujer que elaboró esta idea) aparecen como "ánimas del purgatorio, pues hemos descendido solos a los infiernos, algunos inexplorados, de su historia, para rescatar de ellos lo rescatable, lo irrenunciable. Para ir extrayendo de esa historia sumergida una cierta continuidad. Somos memoria. Memoria que rescata. Ser memoria es ser pasado; mas de muy diferente manera que ser un pasado que se desvanezca sin más, condenado a desvanecerse simplemente. Es lo contrario. Pues nos ven así por identificar nuestra quieta imagen con la de un pasado inasimilable. Mientras que si somos pasado, en verdad es por ser memoria. Memoria de lo pasado en Espańa..." 5. Mirar al exiliado, a ese objeto de mirada,

\footnotetext{
5 Zambrano, M., "Carta sobre el exilio", Cuadernos del Congreso por la libertad de la cultura, no 49, junio de 1961, París, pp. 69-70.
} 
es volver la vista a un pasado difícil de asimilar. Todo fantasma es un asunto del pasado que regresa porque no se halló solución a su conflicto; o bien, ya de inicio este conflicto suyo no fue sacado a la luz, lo que impide su desvanecimiento.

\section{Lugar privado de historia}

El proyecto avanzó, entonces, deslizándose a través de distintas imágenes, o flujos de imágenes relacionadas, que paulatinamente fueron aflorando, reclamadas por los lugares de exilio y escritura. De todo ello mana una historia, sus fantasmas y quienes supieron advertirla. Así José Miguel-Ullán o José Ángel Valente ${ }^{6}$, poetas que se empeñaron en sostener a Zambrano en cuanto objeto de pensamiento y de mirada para una España que parecía no querer asimilar lo que ella traía consigo (el pasado, la historia). Así, casi como si fuese supurada por las imágenes, vino también a comparecer en el proyecto el reclamo del otro margen sobre el que exilio también advierte, el de los que aún permaneciendo en la patria padecieron una privación notable, la de su historia: "Los que se encontraron sin saber cómo ni por qué en aquellos días de la guerra, bajo ella, aprisionados por ella y después por lo que siguió, se vieron así en la vida. Y este "así», es simplemente un estar desprendidos del fluir de la historia. Y ellos vienen a repetir, como en una galería de espejos, la situación del exiliado, su situación de superviviente. Al exiliado le dejaron sin nada, al borde de la historia, solo en la vida y sin lugar; sin lugar propio. Y a ellos con lugar, pero en una historia sin antecedentes. Por tanto, sin lugar también; sin lugar histórico. Pues, ¿cómo situarse, desde dónde comenzar, en un olvido e ignorancia sin límites? Se quedaron sin horizonte. Y por muy en la tierra que estén, en la suya, donde se habla su idioma, donde pueden decir «soy ciudadano», al quedarse sin horizonte, el hombre, animal histórico, pierde también el lugar en lo que a la historia se refiere. No sabe lo que le pasa, no sabe lo que está viviendo. Vive en un sueño." ${ }^{7}$

¿No coincide acaso, esta descripción, con el argumento (la historia, precisamente) que se desenvuelve en El espiritu de la colmena? Este film, que Víctor Erice diri-

\footnotetext{
${ }^{6}$ Y junto con ellos, todos los especialistas en su obra o amigos de María Zambrano que amablemente colaboraron con nuestro proyecto, tanto con la aportación de su testimonio personal como a través de distintos documentos conservados en sus archivos. No podríamos dejar de mencionar a Juan Carlos Marset, Jesús Moreno Sanz, Agustín Andreu, Aquilino Duque, Orlando Blanco, Julio López Cid, Alfredo Castellón, Lucila Valente Palomo, Manuel Ferro, Joaquín Verdú, Fernando Savater, Marifé Santiago Bolaños, Mercedes Gómez Blesa, Emma Giammattei, Claudio Rodriguez Fer, Virginia Trueba... A todos ellos abría que sumar la amable colaboración del cineasta Victor Erice y del crítico de cine Jaime Pena. Estos últimos, en relación al estudio del interés de Zambrano por El espiritu de la colmena.

7 Zambrano, M., "Carta sobre el exilio”, op. cit., p. 69.
} 
gió en 1976, es una auténtica figura de la visión aquí apetecida en nuestra ceguera, y que parece imantada por lo ocurrido, meditado y relatado por Zambrano. Fue en la época de La Pièce cuando Joaquina Aguilar (que en aquél entonces colaboraba con María y con José Ángel Valente en la ordenación de los textos de Claros del bosque) convenció a Zambrano para que la acompañara a un cine de Ginebra y así ver juntas esta película que Erice, en aquel entonces amigo de Joaquina, había realizado. El film conmovió a Zambrano profundamente; quiso ella transmitir al joven director, por tal motivo, todo lo que esa película había despertado en su pensamiento. De las cartas que se cruzaron, hoy desaparecidas, comenta Erice lo mucho que sobrecogió a María el personaje de la pequeña Ana (interpretado en el film por Ana Torrent); si bien, las razones y motivos por los que la pensadora se habría sentido tocada por una obra tan extraordinaria habrían de ser, con toda seguridad, innumerables. Imaginamos que muchos de esos motivos guardan relación con la empatía - y hasta la posible identificación - que la pequeña Ana y su situación pudo estimular en Zambrano. Sobre ello tratamos en el documental, pero permítasenos detenernos solamente, aquí, en el hecho de que El espíritu de la colmena pudo haber mostrado a Zambrano, con tremenda claridad, con el tempo y el tipo de mirada más adecuados, el otro margen de la fractura que ella misma protagonizó, el estado de las cosas en el lugar del que se hallaba forzosamente apartada.

Víctor Erice muestra en su película, efectivamente, lo ocurrido en una Espańa que reafirma permanentemente su autenticidad, pero en la cual parece darse un contraste, no menos crudo, en lo que respecta a su historia. El "lugar de la meseta

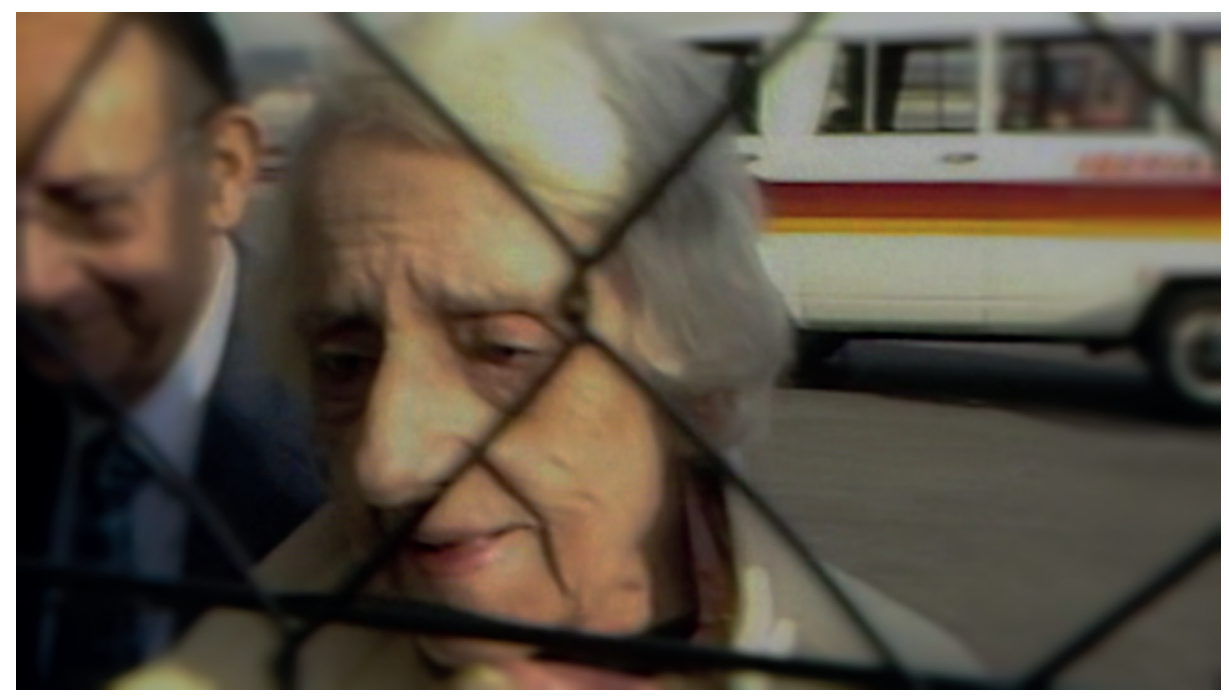


castellana, hacia 1940", en donde se emplaza su argumento, aparece privado de historia, de antecedentes, de un horizonte histórico. La pequeña Ana encaja en el perfil de uno de esos seres a los que aludía Zambrano y que se ven, sin saber cómo ni por qué, desprendidos de una historia. Este personaje de Ana se nos aparece en un lugar "real", aunque sin realidad histórica o sin más realidad en ese sentido que la del silencio. La historia se convierte, frente a su mirada auroral, en un fantasma por ella misma invocado a través de la repetición (como para reafirmar su identidad con dicho mantra) de su propio nombre: "yo soy Ana". Ana, lo sabemos bien quienes admiramos y amamos ese film, vive en un sueño (cinematográfico) que contrasta, a su modo y hasta el punto de mostrarse dolorosamente real también, con el mundo que la rodea y que la niña va descubriendo a golpe de revelaciones. De alguna manera, esta película pone imagen a un pasaje tremendamente importante en la vida y en las meditaciones de Zambrano. La película le trajo, envuelta en un sueño fílmico (a ella que aguardaba en el exilio el momento interminablemente aplazado del retorno) esa parte o ese lugar de su vida del que se había visto privada y que tanto se esforzó en imaginar, en recuperar, en convertir en objeto de mirada.

\section{Salir a la luz}

Más allá de una indudable relevancia artística que no precisa de este tipo de correspondencias para ser reconocida, la película ilustra, con asombrosa fidelidad, multitud de ideas y aspectos que distinguen al pensamiento de María Zambrano. Como ejemplo significativo tomemos el final de El espíritu de la colmena. Ana, insomne y vestida con un holgado camisón de color blanco, abandona su pequeña cama en dirección a un balcón que se encontraría en frente. Ella abre sus puertas, de cristales dorados y cubiertos por una celosía geométrica que imita las celdillas doradas de una colmena. La niña se asoma a una noche blanca para sumergirse en la luz de la luna que entonces baña sus ojos, su mirada. Ana ha terminado por salir a la luz, escenificada esa transición de una manera delicadamente literal. ¿Cómo no fantasear con lo mucho que Zambrano pudo haber visto en esa imagen? Sobre todo si seguimos asociándola a lo que ella misma proponía acerca de lo vivido, dentro de España, por quienes se vieron privados de historia: "Los que en la patria quedaron, crecieron, hablan hoy día -como se puede-, siguen dentro de su sueño; con la realidad, sí, mas una realidad que se les presenta como soñada por desprendida de su ayer, por encerrada en sí misma, por privada de horizonte. Mientras que el exiliado ha venido a tener casi tan sólo horizonte; horizonte sin realidad, horizonte en el que mira, pasa y repasa, desgrana la historia, toda la historia, sobre todo la historia de 
España." ${ }^{8}$ La protagonista de El espiritu de la colmena -sin que esto hubiese sido concebido premeditadamente- es uno de esos seres así descritos por Zambrano; mas se trata de uno que sí alcanzó a despertarse de su sueño sin horizonte, a secundar el desvelamiento hacia el que, por fuerza, el exiliado había sido arrojado: “...Y si se ha ido quedando así, embebido en sí mismo y como ajeno a todo [se refiere Zambrano al exiliado], hasta a su propia historia, es por verla, por estarla viendo cada vez con mayor claridad y precisión, desde ese lugar, en ese límite entre la vida y la muerte donde habita, el cual es el lugar privilegiado para que se dé la lucidez." "También Ana, tras sufrir el desvelamiento de la tragedia que la rodeaba, parece haber alcanzado un privilegio de lucidez (junto con la penitencia que acompañaría a tal privilegio). Esto ocurre así en la película. Y si algún valor ha de concedérsele a nuestro trabajo, que sea el de haber reclamado atención para este tipo de coincidencias. Pese a que, en apariencia, El espiritu de la colmena no concierne a María Zambrano, su descubrimiento por parte de la pensadora terminó convirtiéndola (a la película, esto es lo que buscamos demostrar) en un claro más dentro del método que ella formulaba justo en aquella época. La transición que se muestra al final de la película es una culminación que la tragedia protagonizada por María Zambrano también desea, el gesto de quien abandona una ensoñación, que sale a la luz y mira: "El protagonista de la tragedia puede alcanzar la visión, como Antígona que se encuentra en el peldaño más alto de la escala trágica, en la cima, víctima de sacrificio más que protagonista de simple tragedia. La zozobra que sufre el protagonista de la tragedia proviene de sentirse visto y aun de tener que darse a ver. En el sueño correspondiente, por haber salido a un lugar en donde le aguarda la visibilidad. Los sueños de umbral en que aparece un claro espacio vacío, no son trágicos, pues que el vacío es el lugar de la libertad. Y el umbral a traspasar simboliza el último estadio de la salida de una situación que fue trágica, su consumación y la salida a la personal historia" ${ }^{10}$.

\section{La visión en su cima}

Sin pretender con ello bañar de un lirismo vacuo al gesto, creemos que existe un paralelismo entre las imágenes penumbrosas de la niña que se precipita en luz nocturna (alcanzando así, este personaje, una visión en esa cima argumental) y aquella otra imagen del regreso de María Zambrano a Espańa en el extremo que ocuparía

\footnotetext{
8 Zambrano, M., "Carta sobre el exilio", op. cit., p. 69.

9 Ibid.

${ }_{10}$ Zambrano, M., El sueño creador, Club Internacional del Libro, Madrid, 1998, p. 105.
} 
el tramo final de nuestro ensayo en imágenes. Esta no es una suposición infundada, pues esa misma imagen fue objeto de mirada para Zambrano y sobre ella quiso meditar públicamente la pensadora; las conclusiones de dicha meditación sobre esta imagen, en la que ella misma sale a la luz, acreditan, creemos, nuestras conjeturas:

Al salir de Espańa, en 1939, prevaleció en mí la imagen y la realidad, la realidad que después se hizo imagen, pero una imagen real. Tuvimos que pasar la frontera de Francia uno a uno, para enseñar los más la ausencia de pasaporte, que yo sí tenía [...]. Y el hombre que me precedía llevaba a la espalda un cordero, un cordero del que me llegaba su aliento y que por un instante, de esos indelebles, de esos que valen para siempre, por toda una eternidad, me miró. Y yo le miré. Nos miramos el cordero y yo. El hombre siguió, se perdió por aquella muchedumbre, por aquella inmensidad que nos esperaba del lado de la libertad. ¿Qué hacer ahora? Yo no volví a ver aquel cordero, pero ese cordero me ha seguido mirando. Y yo me decía y hasta creo que llegué a decírselo a media voz a algún amigo o a algún enemigo, o a nadie, o al seńor, o a los olivos, que yo no volvería a España sino detrás de aquel cordero. Y luego he vuelto. Y el cordero no estaba esperándome al pié del avión. Ahora bien, procuré, cuando ya puse el pie en tierra, quedarme completamente sola y pisar la tierra española sola, sin apoyo. Pero el hombre del cordero no estaba. ¿Cuándo he venido a darme cuenta? Pues ahora, cuando, tal vez por misericordia, tal vez por veracidad, me han dicho algunas personas, que estimo, que he llegado a la hora precisa, que he llegado cuando debía llegar y como debía llegar. Y, cuando he visto las imágenes que sacaron los fotógrafos que me aguardaban, tan conmovedoras, tan blancas, tan puras, entonces vi que el cordero era yo. El hombre no aparecía sosteniéndome en su espalda pero yo me había asimilado al cordero [...]. Así, los largos años de exilio me han servido, sin que yo me lo propusiera, pues que de habérmelo propuesto sería una caricatura, o una locura de manicomio simplemente, para irme asimilando al cordero y a aquella mirada indecible, a aquella mirada que no intento transcribir en palabras, a aquel silencio del cordero, un aliento que sentí como vida, como vida de alguien que sabe que está destinado a morir y lo acepta. De alguien que trasciende la muerte misma y que a veces, eso sí, en los paseos que he dado en los campos del Jura -de donde salió el librito Claros del bosque-, permitía que yo viese a lo lejos un cordero [...]. Y yo iba hacia el cordero; y claro está que no llegaba nunca, que no podía llegar por mucho que yo anduviese -y no he sido tan mala andarina-, pues cuando llegaba al lugar no estaba, no era ése su lugar... ${ }^{11}$.

Ella no intentó transcribir en palabras aquella mirada, aquella imagen indecible que es la suya, por la sencilla razón de que esa imagen y esa mirada tienen su lugar propio; están ahí, dispuestas en los documentos que las recogen, para que en su fuente original las descubra quien así lo desee. No transcribe en palabras aquella mirada, también, porque lo necesario es que la misma sea vista más que leída, que pueda cumplir con su ser objeto de mirada. ¿Por qué no habríamos de considerar a esta imagen de su regreso como un resto, que aunque desprendido de su obra

${ }_{11}$ Zambrano, M., "El saber de experiencia (notas inconexas)”, Cátedra, Madrid, 2009, pp. 70-73. 
escrita, entra igualmente en diálogo con sus meditaciones? El motivo del cordero, de la mirada del cordero, cómo dudarlo, es sólo una más de las meditadas alegorías, imágenes o emblemas con los que Zambrano consigue sumergir determinados pensamientos en imágenes que su sensibilidad le reclama. Ella menciona la mirada del cordero como fórmula para aislar un motivo crucial que la imagen contiene. En este texto en donde se refiere a la imagen de su regreso, elige la mención a un cordero porque no hay mejor manera de dar a ver la fugaz docilidad con la que un objeto de mirada se ve así suspendido, abandonado a nuestra atención. También ella quiso, una vez que abandonó el avión, sentirse de nuevo depositada, como suspendida en la tierra a la que regresaba ("sola, sin apoyo"); sentirse a merced de la mirada de los otros. Esa imagen se produjo en una época en la que nuestra televisión pública pudo interrumpir el ensueño cotidiano de los telespectadores espańoles para recoger y dar a ver el gesto; esta es también una circunstancia que sumaríamos a la inercia propicia de su elección, a que ella regresó en un momento adecuado.

Y ha de quedar bien claro que con todo esto no pretendemos sugerir que el modo en que se desenvolvió su regreso tenga absolutamente nada de puesta en escena, aunque escena de un alumbramiento sea. Ella no ejecutó ningún tipo de performance. De habérselo propuesto, así lo reconocía, habría dado lugar "a una caricatura, o una locura de manicomio simplemente". La de Zambrano en la pista de aterrizaje en el aeropuerto de Barajas es una imagen de lejanía mostrándose a punto de cumplir su corporeidad... o quizás ya más allá de la corporeidad que sugiere. En esa imagen existe un instante, de esos indelebles, de esos que valen para siempre, por toda una eternidad, que no admite comentario o palabra alguna, que exige ser sólo y apenas visible; que en la misma medida resiste y queda en suspenso. Quizás sea, sí, la efectiva encarnación de la historia, sueño que está siendo desvelado en una imagen, precisamente en ese instante, precisamente en su instante:

"Toda tragedia poética lleva en su centro un sueño que se viene arrastrando desde lejos, desde la noche de los tiempos y que al fin se hace visible. La visibilidad es la acción propia del autor trágico y del sueño mismo trágico. Todo en principio está ahí, en darse a ver y por eso ese despliegue de un instante, un solo instante en que se abre el abismo infernal del ser humano, donde yace aprisionado, en sus propias entrañas ..." ${ }^{12}$.

José Manuel Mouriño

${ }_{12}$ Zambrano, M., El sueño creador, op. cit., Ibid. 
